\title{
Comparison of Body Compositions Evaluated with Bioelectrical Impedance Analysis (BIA) with Metabolic, Hormonal and Anthropometric Measurements in PCOS Patients
}

\author{
PCOS Hastalarında Biyoelektrik İmpedans Analizi ile Değerlendirilen \\ Vücut Kompozisyonlarının; Metabolik, Hormonal ve Antropometrik \\ ÖIçümlerle Karşılaştırılması
}

\author{
(D)Mahmut Altuntas'1, Hüseyin Aksoy², Tevfik Sabuncu³ \\ 'Family Medicine, Konya ,Turkey \\ ${ }^{2}$ Department of Family Medicine , Adana City Training Research Hospital Adana, Turkey \\ 32Department of Endocrinology, Faculty of Medicine, Harran University, Şanlıurfa, Turkey
}

\begin{abstract}
Aim: In this study, it was aimed to compare the body composition parameters measured by BIA(Bioelectrical Impedance Analysis) and the metabolic, anthropometric and hormonal parameters of the PCOS patients with the healthy control group and to examine the effect of PCOS on body composition parameters. It is aimed to give a better direction to PCOS follow-up and treatment.

Material and Method: 23 non-obese PCOS patients were involved to this prospective study. PCOS diagnosis was made according to the Rotterdam Consensus. Antropometric, metabolic and hormonal parameters were measured. Body compositions were measured by BIA. Results: When the relationship between body composition parameters and metabolic and hormonal values were examined, significant correlations were found. There was a negative correlation between AUC-insulin levels and SHBG while a significant positive correlation between free testosterone in hirsute women with PCOS. There was a significant negative correlation between free testosterone level increase and body fat ratio while a significant positive correlation between SHBG and body fat ratio. There was a significant negative correlation between DHEAS and BMI and the hip circumference. When the relationship between body composition and antropometric parameters were examined, a significant positive correlation was found between BMI and body fat ratio, total body water and basal metabolic rate in women with PCOS.

Conclusion: In this study, significant correlations were found between body compositions and hormonal, metabolic and anthropometric parameters in patients with PCOS. Based on these findings, we believe that BIA can play an important role in outpatient follow-up of patients with PCOS.
\end{abstract}

Keywords: PCOS, Body composition characteristics, BIA, Metabolic, hormonal and antropometric parameters
Öz

Amaç: Bu çalışmada, PCOS'lu ve sağlıklı kontrol grubu hastalarında, vücut kompozisyon parametreleri BIA (Biyoelektrik Impedans Analizi) ile ölçülerek, metabolik, antropometrik ve hormonal parametrelerle karşılaştırılmıştır. Böylece, PCOS'un vücut kompozisyon parametreleri üzerindeki etkileri incelenerek, PCOS takip ve tedavisine daha iyi yön verebilmek hedeflenmiştir.

Gereç ve Yöntem: Bu prospektif çalışmaya 23 obez olmayan PKOS hastası dahil edildi. PCOS tanısı Rotterdam Konsensus Konferansı'na göre konuldu. Antropometrik, metabolik ve hormonal parametreler ölçüldü. Vücut kompozisyonları BIA ile ölçüldü.

Bulgular: Vücut kompozisyon parametreleri ile metabolik ve hormonal değerler arasındaki ilişki incelendiğinde anlamlı korelasyonlar tespit edildi. PCOS'lu kıllı kadınlarda AUC-insülin seviyeleri ile SHBG arasında negatif bir korelasyon varken serbest testosteron arasında anlamlı bir pozitif korelasyon bulundu. Serbest testosteron seviyesi artışı ile vücut yağ oranı arasında anlamlı negatif korelasyon varken, SHBG ile vücut yağ oranı arasında anlamlı pozitif korelasyon tespit edildi. DHEAS ile vücut kitle indeksi (VKI) ve kalça çevresi arasında anlamlı negatif korelasyon bulundu. Vücut kompozisyonları ile antropometrik parametreler arasındaki ilişki incelendiğinde ise, PKOS'lu kadınlarda VKi ile vücut yağ oranı, toplam vücut suyu ve bazal metabolik hız arasında anlamlı pozitif korelasyonlar bulundu.

Sonuç: Bu çalışmada, PKOS' lu hastalarda vücut kompozisyonları ile hormonal, metabolik ve antropometrik parametreler arasında önemli korelasyonlar bulundu. Bu bulgulara dayanarak, basit ve noninvaziv bir yöntem olan BIA'nın PCOS'lu hastaların poliklinik takiplerinde önemli bir yer alabileceği kanaatindeyiz.

Anahtar Kelimeler: PCOS, Vücut kompozisyon karakteristikleri, BIA, Metabolik, hormonal ve antropometrik parametreler 


\section{INTRODUCTON}

Polycystic Ovary Syndrome (PCOS) is a common reproductive and endocrine disorder characterized by hyperandrogenism, anovulation and menstrual dysfunction affecting $5-10 \%$ of women of childbearing age..$^{1,2}$ In PCOS increased incidence of metabolic syndrome components (insulin resistance, impaired glucose tolerance and type 2 diabetes, dyslipidemia, hypertension, and cardiovascular risk profile) have been demonstrated. Obesity is present in $30-75 \%$ of women with PCOS and it is an aggravating factor for clinical entities of metabolic syndrome ${ }^{3,4}$

Currently, there is still no consensus on the etiopathogenesis and diagnostic criteria of PCOS. ${ }^{5}$ Since it is a chronic endocrine and metabolic disorder, it is likely that body composition will change over time. In this study, it was aimed to compare the body composition parameters measured by BIA (Bioelectrical Impedance Analysis) and the metabolic anthropometric and hormonal parameters of the PCOS patients with the healthy control group and to examine the effect of PCOS on body composition parameters that might give better direction to follow-up and treatment of PCOS.

\section{MATERIAL AND METHOD}

This study was conducted at Endocrinology Outpatient Clinic on 23 patients who were admitted by oligo/amenore, weight gain, increased body hair and infertility complaints and diagnosed to have PCOS according to the Rotterdam criteria 6 and on 20 healthy women of similar age and weight. Diabetic patients, steroid preparation users, oral contraceptive users, patients with any systemic (liver, kidney, heart) disease, patients using medicine that can affect insulin resistance for any reason, and smokers were not included in the study. Before the study, ethics committee approval was obtained from Harran University Faculty of Medicine. The standard form for data including identification information, age, height and weight, medical and gynecological history and physical examination findings has been filled.

\section{Metabolic and Hormonal parameters}

The study group received standard $75 \mathrm{~g}$ oral glucose tolerans test (OGTT) to assess insulin resistance. Serum glucose (mg/ dl) and insulin (ulU/ml) levels were measured in these blood samples. The area under the curve (AUC) for glucose and insulin was calculated from these values by trapezoidal rule. AUC-Glucose and AUC-Insulin were used as mixed variables in data analysis reflecting blood glucose and insulin levels. The insulin sensitivity index (ISI) was calculated using the ISIComposite formula described by Matsuda and De Fronzo, which is as valuable as the gold standard clamp technique.

Triglyceride, total cholesterol, HDL-cholesterol and LDLcholesterol values were measured in blood samples taken after at least 10 hours of fasting. Blood samples were taken between days 3 and 8 of the menstrual cycle for hormonal evaluation. TT, fT, Östradiol, PRL, DHEAS, SHBG, Cortisol levels were measured. A $1 \mathrm{mg}$ dexamethasone suppression test was performed to exclude Cushing's disease in all the patients. At $11.00 \mathrm{pm}, 1 \mathrm{mg}$ dexamethasone was applied and at $8.00 \mathrm{am}$ patients with venous cortisol level of $3 \mathrm{mcg} / \mathrm{dl}$ or less were considered normal.

\section{Antropometric parameters}

At the time of initial admission Body mass indexes (BMI) in $\mathrm{kg} / \mathrm{m}^{2}$ were calculated by measuring the height $(\mathrm{m})$ and weight $(\mathrm{kg})$ of the patients and waist circumference, hip circumference, waist/hip circumference ratio were measued.

\section{Body Composition Parameters Measured By Bioelectrical Impedance Analysis}

In the morning of the day when anthropometric measurements were made, after at least 8 hours of rest, BIA was performed on the two groups of patients with empty stomach and empty bladder. Biodynamics BIA 450, USA, Bioimpedance Analyzer was used in the procedure. The patients were told to drink 7-8 glasses of water a day before the procedure, and not to drink much tea/coffee and not to smoke many cigarettes. The metal and decorative items on the patient and, if any, large metal clothing items (such as belts) were removed. The individual to be measured was asked to stay in supine position on the examination table with dress but without shoe and socks. For measurement, two electrodes were placed on the dorsal side of the right hand and right wrist and two electrodes were placed on the dorsal side of the right foot and the right ankle (using standard tetrapolar electrodes). Afterwards, the instrument was turned on and the required information was entered and the measurement was performed. Body fat ratio (BFR), fat mass (FM), total body water (TBW), basal metabolic rate (BMR), lean body mass (LBM) were measured by BIA.

\section{Statistical Analysis}

Anthropometric parameters, metabolic parameters and body composition parameters measured by BIA were compared between the study group and the control group. SPSS (Statistical Package for Social Sciences) for Windows 11.5 program was used for the statistical analysis. For descriptive statistical methods (Mean, Standard deviation) and for comparison of normally distributed quantitative data.of study and control group Student $t$ test was used. Man Witney $\mathrm{U}$ test was used for non-normal distribution parameters . Chi-square test was used for comparison of qualitative data. Pearson correlation test was used for normal distribution parameters and Spearman's correlation test was used for non-normal distribution parameters. The results were evaluated in a $95 \%$ confidence interval and a significance level of $p<0.05$.

\section{RESULTS}

There were 23 women with PCOS who had a BMI of 18.91$26.93 \mathrm{~kg} / \mathrm{m}^{2}$ between 18 and 32 years $(22.0 \pm 3.43)$, and 20 women with a BMI of $18.26-24.97 \mathrm{~kg} / \mathrm{m}^{2}$ between 17 and 33 years $(24.0 \pm 4.02)$ were included in the study . 
When we compare the hormonal and metabolic parameters, there was a significany in LH, TT, fT, SHBG. As to be aspected, the LH, TT anf fT levels were significantly higher in PCOS group while SHBG level were significantly low. Ferriman Galwey score were also significantly higher in PCOS group $(p<0.001)$. When lipid profiles, metabolic parameters were compared and there was no statistically significant difference ( $p>0.05$ ) (Table 1).

Table 1. Comparison of hormonal and metabolic parameters of study

\begin{tabular}{lccc} 
groups & $\begin{array}{c}\text { PCOS Group } \\
(\mathbf{n}=\mathbf{2 3})\end{array}$ & $\begin{array}{c}\text { Control Group } \\
(\mathbf{n = 2 0 )}\end{array}$ & P \\
\hline FSH $(\mathrm{mlU} / \mathrm{ml})$ & $4.61 \pm 1.32$ & $5.33 \pm 4.76$ & $>0.05$ \\
$\mathrm{LH}(\mathrm{mlU} / \mathrm{ml})$ & $12.79 \pm 6.32$ & $6.23 \pm 3.12$ & $<0.001$ \\
TT $(\mathrm{ng} / \mathrm{dl})$ & $70.90 \pm 26.09$ & $46.8 \pm 17.5$ & $\mathrm{p}=0.001$ \\
$\mathrm{fT}(\mathrm{pg} / \mathrm{ml})$ & $12.22 \pm 5.56$ & $6.87 \pm 4.46$ & $<0.001$ \\
SHBG $(\mathrm{nmol} / \mathrm{L})$ & $40.37 \pm 21.07$ & $75.36 \pm 60.60$ & $<0.05$ \\
DHEAS(ug/dl) & $268.52 \pm 117.85$ & $245.34 \pm 124.05$ & $>0.05$ \\
AUC glucose & $199.16 \pm 40.96$ & $207.22 \pm 42.39$ & $>0.05$ \\
AUC insulin & $80.67 \pm 29.64$ & $88.21 \pm 5060$ & $>0.05$ \\
ISI & $7.06 \pm 2.79$ & $6.66 \pm 2.64$ & $>0.05$ \\
Basal Metabolic Speed (cal) & $1264.6 \pm 20.1$ & $1078.9 \pm 397.7$ & $>0.05$ \\
Ferriman-Galwey Score & $13.91 \pm 4.89$ & $5.80 \pm 1.43$ & $<0.001$ \\
\hline Mean \pm SD & & & \\
\hline
\end{tabular}

Between study groups there was also no statistically significant difference in the anthropometric measurements and in the body composition components ( $p>0.05$ ) (Table 2).

Table 2. Comparison of anthropometric and body composition values of study groups

\begin{tabular}{lccc} 
& $\begin{array}{c}\text { PCOS Group } \\
(\mathbf{n = 2 3 )}\end{array}$ & $\begin{array}{c}\text { Control Group } \\
(\mathbf{n = 2 0 )}\end{array}$ & P \\
\hline Waist Circumference (cm) & $70.56 \pm 5.11$ & $68.35 \pm 7.07$ & $>0.05$ \\
Hip Circumference (cm) & $94.21 \pm 7.70$ & $92.1 \pm 9.84$ & $>0.05$ \\
Waist/Hip ratio & $0.75 \pm 0.04$ & $0.74 \pm 069$ & $>0.05$ \\
Fat Mass (kg) & $14.42 \pm 4.04$ & $14.33 \pm 2.90$ & $>0.05$ \\
Body fat ratio (\%) & $26.12 \pm 5.58$ & $26.26 \pm 5.77$ & $>0.05$ \\
LBM (\%) & $40.53 \pm 6.44$ & $38.32 \pm 5.12$ & $>0.05$ \\
TBW (liter) & $30.33 \pm 3.80$ & $29.03 \pm 2.84$ & $>0.05$ \\
\hline Mean \pm SD & & & \\
\hline
\end{tabular}

However, when correlation of androgenemias and FerrimanGalwey scores with BMI, body composition values, AUCinsulin AUC-glucose and ISI were examined in patients with PCOS, there was significant negative correlation between insulin sensitivity and total and free testosterone levels in hirsute women with PCOS ( $r=-0.448, p<0.05, r=-0.538, p<0.01$, respectively) (Table 3 ). There was a negative correlation between SHBG and AUC-insulin levels $(r=-0.540, p<0.01)$ and a significant positive correlation between free testosterone increase and AUC-insulin levels $(r=0.06, p<0.01)$.
In hirsute women with PCOS, there was a significant negative correlation $(r=-0.544, p<0.01)$ between free testosterone level increase and body fat ratio and a significant positive correlation $(r=0.544, p<0.01)$ with lean body mass. In women with PCOS, there was a significant positive correlation between SHBG and body fat ratio $(r=0.418, p<0.05)$ and a negative correlation with DHEAS $(r=-0.572, p<0.01)$. There was a significantly positive correlation between lean body mass and DHEAS $(r=0.572$, $\mathrm{p}<0.01)$. There was a significant negative correlation between DHEAS and BMI and the hip circumference $(r=-0.584, p<0.01$; $r=-0.425, p<0.05$, respectively). However, there was no significant relationship between free testosterone level and BMI, waist circumference, hip circumference and waist/hip ratio.

When the relationship between body composition and antropometric parameters were examined, a significant positive correlation was found between BMI and body fat ratio, total body water and basal metabolic rate in women with PCOS $(r=0.609, p<0.01 ; r=0.414, p<0.05 ; r=0.455, p<0.05)$ while the fat-free body mass showed a significant negative correlation with BMI $(r=-0.609, p<0.05)$.There was a strong positive correlation between total body water and waist circumference $(r=0.616, p<0.01)$ and a positive correlation between total body water and hip circumference $(r=0.491$, $\mathrm{p}<0.05)$.

There was a strong positive correlation between basal metabolic rate $(B M R)$ and waist circumference and hip circumference $(r=0.646, p<0.01 ; r=0.537, p<0.01$, respectively (Table 4).

When the relationship between body composition values and metabolic parameters is examined, there was a significant negative correlation between insulin sensitivity (ISI) and total body water $(r=-0.514, p<0.05)$, while a significant negative correlation was found between ISI and basal metabolic rate $(r=-0.539, p<0.01)$. Lipid profile values and anthropometric and body composition characteristics were not significantly correlated (Table 5).

Table 4. The association of body composition parameters with clinical metabolic and hormonal values $(r)$

\begin{tabular}{lcccc} 
& BFR (\%) & LBM (\%) & TBW(\%) & BMR(cal) \\
\hline BMI & $0.609^{\mathrm{b}}$ & $-0.609^{\mathrm{b}}$ & $0.414^{\mathrm{a}}$ & $0.455^{\mathrm{a}}$ \\
Waist Circumference & 0.315 & -0.315 & $0.616^{\mathrm{b}}$ & $0.646^{\mathrm{b}}$ \\
Hip Circumference & 0.296 & -0.296 & $0.491^{\mathrm{a}}$ & $0.537^{\mathrm{b}}$ \\
Waist/Hip Ratio & -0.045 & 0.045 & 0.098 & 0.074 \\
LH & -0.160 & 0.160 & 0.190 & 0.186 \\
TT & $-0.503^{\mathrm{a}}$ & $0.503^{\mathrm{a}}$ & 0.399 & 0.374 \\
fT & $-0.544^{\mathrm{b}}$ & $0.544^{\mathrm{b}}$ & 0.289 & 0.258 \\
SHBG & 0.160 & -0.160 & 0.167 & 0.180 \\
DHEAS & $-0.572^{\mathrm{b}}$ & $0.572^{\mathrm{b}}$ & 0.067 & 0.039 \\
AUC-glucose & -0.100 & 0.100 & 0.170 & 0.191 \\
AUC-insulin & -0.254 & 0.254 & 0.405 & 0.405 \\
ISI & 0.137 & -0.137 & $-0.514^{\mathrm{a}}$ & $-0.539^{\mathrm{b}}$ \\
\hline $\mathrm{a}=\mathrm{p}<0.05 \quad \mathrm{~b}=\mathrm{p}<0.01$ & & & &
\end{tabular}




\begin{tabular}{|c|c|c|c|c|c|c|}
\hline & LH & TT & fT & SHBG & DHEAS & FGs \\
\hline Waist Circumference & 0.062 & 0.007 & -0.030 & 0.143 & -0.310 & -0.436 \\
\hline Waist/Hip Ratio & -0.011 & -0.202 & 0.066 & -0.132 & 0.260 & 0.001 \\
\hline BFR & -0.110 & $-0.503^{\mathrm{a}}$ & $-0.544^{b}$ & $0.418^{\mathrm{a}}$ & $-0.572^{b}$ & $-0.525^{a}$ \\
\hline LBM & -0.609 & $0.503^{\mathrm{a}}$ & $0.544^{b}$ & -0.018 & $0.572^{\mathrm{b}}$ & $0.525^{\mathrm{a}}$ \\
\hline AUC-insulin & 0.228 & 0.369 & $0.06^{\mathrm{b}}$ & $-0.540^{\mathrm{b}}$ & $0.422^{\mathrm{a}}$ & 0.126 \\
\hline$|S|$ & -0.035 & $-0.448^{a}$ & $-0.538^{b}$ & 0.361 & -0.282 & 0.089 \\
\hline
\end{tabular}

Tablo 5. The association of anthropometric and body composition values with metabolic parameters ( $r$ )

\begin{tabular}{|c|c|c|c|c|c|c|c|}
\hline & AUC-glucose & AUC-insulin & ISI & Trigliseride & Cholesterol & LDL & HDL \\
\hline BMI & 0.004 & -0.086 & -0.130 & 0.015 & 0.196 & 0.208 & 0.016 \\
\hline BFR & -0.100 & -0.254 & 0.137 & 0.071 & 0.204 & 0.152 & 0.075 \\
\hline LBM & 0.100 & 0.254 & -0.137 & -0.071 & -0.204 & -0.152 & -0.075 \\
\hline BMR & 0.191 & 0.405 & $-0.539^{b}$ & -0.028 & 0.130 & 0.122 & 0.069 \\
\hline Waist C. & -0.038 & 0.117 & -0.267 & -0.038 & 0.140 & 0.086 & 0.153 \\
\hline
\end{tabular}

\section{DISCUSSION}

In this study we found that there was no statistically significant difference in the metabolic parameters, anthropometric measurements and in the body composition components between PCOS and control group. However, when correlation of androgenemias and Ferriman - Galwey scores with BMI, body composition parameters and metabolic parameters were examined significant correlations were found.

Insulin resistance is thought to play an important role in the pathophysiology of PCOS in recent years as it is known that insulin directly affects the production of in vitro ovarian androgen and in many PCOS patients insulin resistance and hyperinsulinemia are present independent of obesity. ${ }^{7-9}$ In our study, a negative correlation was found between total and free testosterone levels and insulin sensitivity. In hirsute women with PCOS there was a significant positive correlation between free testosterone increase and AUC-insulin levels. Negative correlation was found between AUC insulin and SHBG levels. This supports the information in the literature about the association of hyperinsulinemia with hyperandrogenic activity.

Georgopoulos et al. reported that in hirsute women with PCOS, BMR evaluated by indirect calorimetry was decreased compared with control subjects, independently of obesity and IR. Adjusted BMR was significantly decreased both in women with PCOS with or without IR and particularly in women with PCOS and IR. ${ }^{10}$ In our study, we also found that the BMR decreased as insulin sensitivity increased in patients with PCOS. We additionally found that total body water also decreased as insulin sensitivity increased in PCOS patients compared to control group.
Different publications have been reported in the literature regarding the body composition of PCOS patients. Geronikolou et al. made ECW, TBW, FM, and LBM and ICW measurements in their study with BIA in adolescents with PCOS and found similar results with the control group. The fact that the study was in the adolescent age group and limited sample size may have affected the results. ${ }^{11}$ However, the hormonal parameters were not studied in this study. Studies have shown that androgen excess and adipose tissue hypertrophy play a role in the pathophysiology of PCOS. ${ }^{12}$ In our study we found some correalations between hormones and body composition parameters in hirsute patients with PCOS. As free testosterone, total testesteron and DHEAS increases, BFR decreases and LBM increases. Additionally there was a positive corrrealation found between SHBG and BFR which means that the increase of SHBG leads to an increased level of BFR.

Churchill et al. reported that after adjusting age and BMI, there was no significant difference in BMR between PCOS women and controls. ${ }^{13}$ Although age and body mass index similar groups were selected in our study, it was found that BMR increased statistically significantly as BMI increased in patients with PCOS. In these patients, it was also found that body fat ratio and TBW were statistically significantly higher. In addition, we found that as the waist and hip circumference increased in patients with PCOS, BMR and total body water increased significantly. It was found that waist and hip circumference was significantly higher in PCOS patients with higher TBW and insulin sensitivity was decreased in these patients.

On the other hand, we want to emphysize that various methods of determining body composition have been developed. 
With such sophisticated methods, body composition can be determined much closer to real values. However, a significant portion of these methods (such as densitometers, CT, MRI, DEXA) are not used for routine clinical and epidemiological studies because they require expensive equipment and consumables, and are impractical.

The bioelectrical impedance analysis (BIA) method developed in recent years is a method based on determining the permeability of a weak electrical current in the human body. BFM, BFR, LBM, TBW and ratio can be determined by using the related formulas in the obtained permeability data. Studies have shown that the findings obtained with the BIA method are similar to those obtained with complex methods (densitometer, total body water calculation, etc.) so that makes use of the BIA method in policlinic work more common. ${ }^{14,15}$

\section{CONCLUSION}

In this study, we found significant correlations between the body compositions measured by the BIA and other hormonal, metabolic and antropometric parameters. In future, we believe that BIA, which is a simple and noninvasive method, can take an important place in the outpatient clinic follow-up of patients with PCOS.

\section{ABBREVIATIONS}

AUC: Area under the curve, BFM: Body fat mass, BFR: Body fat ratio, BIA: Bioelectrical impedance analysis, BMI: Body mass index, BMR: Body mass ratio, DHEAS: Dehydroepiandrosterone sulfate, FGs: Ferriman-Galwey score, FSH: Follicle-stimulating hormone, fT: Free testesteron, HDL: high-density lipoprotein, ISI: Insulin sensitivity index, LBM: Lean body mass, LH: Luteinizing hormone, LDL: Low-density lipoprotein, OGTT: Oral glucose tolerance test, PCOS: Polycystic Ovary Syndrome, SHBG: Sex hormone -binding globülin, TBW: Total body water, TT:Total testesteron

\section{ETHICAL DECLARATIONS}

Ethics Committee Approval: Ethics committee approval was obtained from Harran University Faculty of Medicine (06/ 29.03.2007).

Informed Consent: All patients signed the free and informed consent form.

Referee Evaluation Process: Externally peer-reviewed. Conflict of Interest Statement: The authors have no conflicts of interest to declare.

Financial Disclosure: The authors declared that this study has received no financial support.

Author Contributions: All of the authors declare that they have all participated in the design, execution, and analysis of the paper, and that they have approved the final version.

\section{REFERENCES}

1. Tharian K, Warner J. Polycystic ovarian syndrome in adolescent girls. Paediatr Child Health 2011;21(7): 309e314.

2. Sirmans, S.M., and K.A. Pate. Epidemiology, Diagnosis, and Management of Polycystic Ovary Syndrome. J Clin Epidemiol 2013;6:1-13.

3. Ali AT. Polycystic ovary syndrome and metabolic syndrome.Ceska Gynekol. 2015;80(4):279-89.

4. Bañuls C, Rovira-Llopis S, Martinez de Marañon A et al. Metabolic syndrome enhances endoplasmic reticulum, oxidative stress and leukocyte-endothelium interactions in PCOS. Metabolism. 2017;71:153 162.

5. Kamboj MK, Bonny AE. . Polycystic ovary syndrome in adolescence: diagnostic and therapeutic strategies. Transl Pediatr. 2017;6(4):248-255.

6. Rotterdam ESHRE/ASRM-Sponsored PCOS Consensus Workshop Group. Revised 2003 consensus on diagnostic criteria and long-term health risks related to polycystic ovary syndrome. Fertil Steril 2004;81:19-25.

7. Bednarska S, Siejka A. The pathogenesis and treatment of polycystic ovary syndrome: What's new? Adv Clin Exp Med. 2017;26(2):359-367.

8. Li Y, Chen C, Ma Y et al. Multi-system reproductive metabolic disorder: significance for the pathogenesis and therapy of polycystic ovary syndrome (PCOS). Life Sci. 2019;228:167-175.

9. Diamanti-Kandarakis $E$, Dunaif $A$. Insulin resistance and the polycystic ovary syndrome revisited: an update on mechanisms and implications. Endocr Rev. 2012;33(6):981-1030.

10. Georgopoulos NA, Saltamavros AD, Vervita $V$ et al. Basal metabolic rate is decreased in women with polycystic ovary syndrome and biochemical hyperandrogenemia and is associated with insulin resistance. Fertil Steril. 2009;92(1):250-5.

11. Geronikolou SA, Bacopoulou F, Cokkinos D. Bioimpedance Measurements in Adolescents with Polycystic Ovary Syndrome: A Pilot Study. Adv Exp Med Biol. 2017;987:291-299.

12. Dimitriadis, G.K., I. Kyrou, and H.S. Randeva. 2016. Polycystic Ovary Syndrome as a Proinflammatory State: The Role of Adipokines. Current Pharmaceutical Design 2016;22(36):5535-5546.

13. Churchill SJ., Wang E, Bhasin G et al. Basal metabolic rate in women with PCOS compared to eumenorrheic controls. Clin Endocrinol 2015; 83 384-388.

14. Barbosa-Silva MC, Barros AJ. Bioelectrical impedance analysis in clinical practice: a new perspective on its use beyond body composition equations. Curr Opin Clin Nutr Metab Care. 2005 May;8(3):311-7. Review.

15. Kyle UG, Bosaeus I, De Lorenzo AD et al. Bioelectrical impedance analysispart II: utilization in clinical practice. Clin Nutr. 2004 Dec;23(6):1430-53 